\title{
A 'great way to get on'? The early career destinations of Science, Technology, Engineering and Mathematics graduates
}

\author{
Emma Smith* and Patrick White \\ School of Education \\ University of Leicester \\ Leicester \\ LE1 7RH
}

\begin{abstract}
Concerns about a shortage of highly skilled workers in the science, technology, engineering and mathematics (STEM) sectors have been expressed frequently since the late 1940s. Although these claims have been challenged as being insufficiently grounded in evidence, they have formed the basis of policies directing considerable resources to STEM education, particular in the university sector. This paper uses data from the Higher Education Statistical Agency (HESA) from 1994 to 2010, and covering more than 3 million UK graduates, to contribute to existing research into the purported skills gap in the STEM sector. It examines their destinations six months after graduation to establish the proportion of graduates from different subject areas that enter graduate careers, with a particular focus on STEM graduates and highly skilled STEM occupations. The findings show that only a minority of graduates enter 'graduate' positions within six months of finishing their degree and many find themselves unemployed or underemployed. Overall, STEM graduates fare little better than non-STEM graduates and while graduates in some STEM subjects fare slightly better than average, those with other STEM degrees fare worse than those with non-STEM degrees. The findings appear incompatible with a true shortage of potential STEM workers and raise questions about employers' expectations and the continued subsidisation of STEM degrees.
\end{abstract}

\section{Introduction}

Recent media accounts have reported that there is a problem with the supply of highly skilled workers in the areas of science, technology, engineering and mathematics (STEM) (e.g. The Telegraph 2013, BBC 2014). Claims are frequently made, by both industry and governmental bodies, that the supply of STEM graduates is crucial to the current and future economic prosperity of the nation and that employers are currently unable to recruit a sufficient number of workers with the right skills (e.g. CBI 2014, Select Committee on Science and Technology 2012). A shortage of adequately skilled STEM workers, it is argued, is holding back economic growth and placing UK industry at a disadvantage in relation to international competitor countries (CIHE 2009, CBI 2014a).

These accounts have not gone unchallenged, however, and other commentators have argued that the supply of STEM skills is more than enough to meet demand and that the picture is much healthier than is often suggested. Instead of there being a shortage of STEM professionals, critics of the shortage debate claim that many highly qualified STEM 
graduates, either: struggle to find appropriate employment and can only find work in nonSTEM fields; are 'underemployed' in STEM occupations that do not require their full range of skills and knowledge; or are unemployed (UKCES 2011, Harris 2014, see Teitelbaum 2014 for a US perspective on STEM shortages).

Whether a sufficient number of highly qualified STEM workers are being educated and trained in the UK is an important question. The answer has implications not only for educators, employers and policy makers but also individuals who are currently engaged in, or are considering entering, education or training in this area. At the moment, however, there is insufficient evidence to resolve this debate. In order to do so it is necessary to determine whether shortages actually exist, the extent of any shortages, and exactly what skills - if any - are in short supply (Select Committee on Science and Technology 2012). The research reported in this paper uses existing data to examine the early career destinations of STEM graduates from UK universities. The research presented here spans the 17 year period between 1994 and 2010 and examines the destinations of over 3 million undergraduate leavers from higher education in the UK.

In particular, it addresses the following research questions:

- In the period between $1994 / 5$ and 2010/11, what activities were recent UK graduates engaged in six months after leaving university?

- What are the first occupational destinations of STEM graduates?

- To what extent have the destinations of STEM graduates varied since the mid-1990s?

- To what extent do early graduate occupational destinations vary between different STEM subjects?

- How do the destinations of STEM graduates compare with those who graduate from non-STEM subject areas?

The paper begins with an examination of the graduate labour market in the context of the expanding UK higher education sector before narrowing its focus to graduate STEM employment.

\section{The graduate labour market}

Over the last fifty years, higher education (HE) in the UK has moved from being an elite to a mass experience (Furlong and Cartmel 2009). In 1963 just 8.5\% of the British population went to university; by 2010 this figure was closer to $40 \%$ (Chowdry et al. 2010). The HE sector now contributes around $£ 59$ billion to the economy and attracts over 400,000 non-UK domiciled students (BIS 2009, HESA 2015). We are told that the benefits of a university education lie not only in securing academic qualifications; studying in Higher Education will significantly influence one's life chances and earning potential (BIS 2011) and graduates are more likely to have better jobs, enjoy better health and live longer than those who do not have a degree (Marmot Review 2010). Through their commitment to policies and initiatives to both increase and widen participation (for example, DfES 2003), successive governments 
have reinforced the notion that going to university is a 'great way to get on' (Denham 2008, n.p.).

The expansion of the UK HE system over the last 25 years has been reflected in a quadrupling of the number of candidates accepting places to study at undergraduate-level. This increase is particularly apparent among some previously under-represented groups: in 1987 , fewer than 50,000 women accepted places on undergraduate courses; by 2014 this had risen to 250,000 (Smith 2010, UCAS 2015).

This increase in and widening of participation has raised concerns about whether labour market demand for graduates has kept up with the supply or whether increasing numbers of graduates find themselves in non-graduate jobs for which they may be over-qualified (e.g. Dolton and Silles 2003, Elias and Purcell 2004, Green and Zhu 2010, Elias and Purcell 2013). According to Chevalier (2000), having an over-educated graduate population may lead to a number of potential consequences: traditional non-graduate jobs being 'up-graded' to graduate jobs; graduates being recruited to jobs that do not require graduate-level skills; or employers raising their qualification requirements. Additionally, with more young people entering HE, the pool of well qualified school-leavers may be depleted, leading to some employers being forced to recruit graduates for jobs that were previously filled by 16 to 18 year olds.

Although concerns that university graduates are taking jobs that do not require a university degree are commonly aired (e.g. Wolf 2000), the current lack of evidence makes it difficult to provide a coherent and detailed picture of the situation. Much of the existing research in this area has been conducted at different periods of time and has used different ways of defining and measuring key concepts such as over-education or underemployment. For example, according to Dolton and Vignoles $(2000: 180)$ over-education is defined as 'a graduate in a job requiring sub-degree level qualifications (or no qualifications at all)'. However, Chevalier $(2000,2009)$ measures over-education by examining an individual's self-reported satisfaction of the match between their occupational role and their own qualifications. Given the different definitions that are used, it is not surprising that estimates of the numbers of underemployed graduates vary. Elias and Purcell (2004) and Mosca and Wright (2011) estimate that 20\% to $25 \%$ of graduates are in non-graduate jobs $3 \frac{1}{2}$ years after graduation, Chevalier (2009) finds that around a third of graduates were over-educated six or seven years after graduation, and Dolton and Vignoles (2000) have the figures as 38\% of graduates being over-educated for their first job and 30\% still underemployed six years later. However, even the most conservative estimates suggest that this issue affects a substantial proportion of graduates, not only immediately following graduation but often for several years afterwards.

For some graduates, taking jobs that require less than a university degree may be a short-term situation that could lead to longer-term benefit. Some work temporarily in jobs that provide them with the skills for higher-level positions later on in their careers. However there is concern that accepting non-graduate jobs immediately after graduation could be linked to under-employment in future positions and therefore the first job that a graduate takes after 
leaving university could be crucial for their future employment trajectories. According to Dolton and Silles (2003:191):

A lower-level position in first employment may be difficult to recover from due to the obsolescence of skills that are not being used. Alternatively once an individual has been in a lower-grade job it may be harder to 'trade-up' to a more demanding job as an employer could take their earlier experience as a negative signal of low ability and/or motivation.

Mosca and Wright's (2011) research supports this view, finding that the first job after graduation is important in terms of later-life occupation. For example, graduates who were in non-graduate employment six months after graduation were more likely to still be underemployed 42 months later. Being over educated in one's first job could, as Dolton and Vignoles (2000:211) fear, 'permanently hold graduates in lower-level occupations throughout their careers'.

Despite the willingness of recent government administrations to encourage the expansion of higher education and to raise the proportion of young (and older) people studying for undergraduate degrees, concerns have been raised that not all of the effects of this expansion have been positive. While employers continue to report skill shortages and difficulties in recruiting suitably qualified graduates (CBI 2014, 2014a) there is some evidence to suggest that a sizeable minority of graduates are unable to find a 'graduate job' even several years after finishing their degrees. This situation is not incompatible with a skills shortage but raises questions about the type and level of skills employers expect and the extent to which a university education can provide them.

This debate is not new and neither is it restricted to a single labour market sector or degree subject. However, claims of skills shortages have a longer history and have been more visible in some areas. Nowhere is this concern more apparent than in the STEM sector.

\section{The supply and demand of STEM workers}

Improving the recruitment, retention and training of the next generation of STEM professionals has been an area of perennial concern for policy makers and employer organisations in the UK and elsewhere (e.g. HM Treasury 2014, National Academy of Sciences 2010, European Commission 2007, Gago et al., 2004). 'Crisis' accounts of falling levels of engagement in STEM subjects at local and international levels can be traced back to the end of the Second World War or even earlier (e.g. Bush 1945, see Author). According to the Confederation of British Industry's recent Skills and Education Survey, there is a widespread shortage of STEM skills, with 39\% of employers reporting difficulty in recruiting appropriately skilled applicants and more than half expecting to experience recruitment problems within the next three-years (CBI 2014). Surveys by the Sector Skills Council and other organisations paint a similar picture (e.g. IET 2013). In a society with increasing demands for scientific- and technological-based goods and services, a shortage of appropriately skilled workers is, according to some, a threat to our 'productivity, competitive position and level of innovation' (Greenfield et al. 2002:27). 
These concerns are reflected in the range and scope of initiatives and policies that have aimed to raise young people's participation in STEM subjects. The rationale behind such initiatives has largely been economic and echo industry's concern for a suitably skilled workforce (e.g. CBI 2014), particularly in the face of competition from other established and emerging economies such as India and China (Leitch Review of Skills 2006). STEM subjects occupy a privileged position in UK government Higher Education policy. They have enhanced status as 'strategically important and vulnerable' (SIV) subjects ${ }^{1}$ (HEFCE, 2008) and, in the context of recent funding cuts to the HE sector in England, have been a key area identified for 'enhanced support' by recent governments (e.g. DIU 2009). One consequence of the perceived failure of the UK to adequately recruit, train and retain the next generation of professional scientists has been huge government investment in the sector. For example, the 2010-15 Parliament provided $£ 185$ million to support the teaching of high cost STEM subjects in higher education and committed $£ 7.2$ million to provide support to science teachers through the National Science Learning Network between 2014 and 16 (HM Treasury 2014).

The existence of a STEM 'skills deficit', however, has not gone unchallenged. As far back as the 1950s, widespread political concerns about a 'swing from science' and a 'brain drain' of highly qualified professionals were being questioned by economists who saw the issue as a 'mass of contradictions compounded by a lack of understanding about what labour market demand actually meant' (Gannicott and Blaug 1969:57, see also Wilkinson and Mace 1973 and Author). More recent work into the supply and demand of high level STEM skills, undertaken on behalf of the UK Commission of Employment and Skills, found that the available data do not suggest a higher vacancy rate for jobs that require workers with STEM skills, neither do they reveal an overall shortage of STEM graduates (UKCES 2011, 2013). Such contradictions are not limited to the UK. Writing from a US perspective, Teitelbaum (2003:47) argues that STEM shortage claims are 'inconsistent with all available quantitative evidence ... [and] many of the solutions proposed to deal with the putative "crisis" are profoundly misdirected'. The economist Paul Krugman has described the purported skills gap as 'a prime example of a zombie idea - an idea that should have been killed by evidence, but refuses to die' (Krugman 2014:A21). While shortage claims have frequently been challenged by research findings, the rhetoric contained in these 'crisis accounts' is strong and the 'shortage' discourse has succeeded in becoming the dominant political and public view. As a consequence, alternative accounts are largely absent from wider discussion which, in turn, has served to 'confuse serious thinking and to distort public policy' (Teitelbaum 2014:26).

Most of the proposed solutions to the apparent STEM recruitment crisis focus mainly on the supply side, urging action to increase the numbers of students pursuing degrees in science and engineering. However, as Wright and Sissions (2012) have noted, effective policy cannot be made without detailed and accurate data on the demand for labour in the sector. The currently available data on the demand for STEM workers is both inconsistent and partial, and there is a lack of detailed and reliable evidence in this area, a concern reflected in the conclusions of a House of Lords select committee:

'The lack of reliable data on the supply and demand for STEM graduates and postgraduates makes it very difficult to assess whether there is a shortage of STEM 
graduates and postgraduates, and in which sectors' (Select Committee on Science and Technology, 2012, para 72).

There is clearly a need for more informative analysis of the data available in this area. This paper aims to contribute to this debate by examining data on the destinations of UK graduates from 1994 to 2011.

\section{Data and analysis}

The research reported in this paper used data retrieved from the Higher Education Statistical Agency (HESA) to investigate the activities of more than 3 million first degree graduates from STEM and non-STEM programmes at UK universities. It uses data on graduate destinations over a seventeen year period (from 1994 to 2011) and presents detailed coverage of trends in different subject areas (both STEM and non-STEM). These data are collected by HESA as part of their Destinations of Leavers from Higher Education (DLHE) survey that gathers data from all students approximately six months after they have left university. Respondents are asked about the type of work in which they are employed, whether they have embarked upon further study and so on. Some of the data are also linked to the HESA Student Record and this enables analysis of destinations by students' subject of study. The data are collected through questionnaires sent out to their graduates by Higher Education institutions. For those who graduated between January and July, the data are for respondents' employment situation the following January. For individuals who graduated between August and December, the data relate to their employment situation the following April (HESA 2012).

This paper focuses exclusively on first destinations six months after graduation. While other studies have used HESA's longitudinal destination data on the graduate population 3.5 years after graduation (e.g. Gittoes 2008), this survey is sample-based and has a low response rate (22\% for the 2012 survey (HESA 2013)). In contrast, the six-month destinations survey aims to collect data from the entire UK graduate population and has a much higher response rate (typically around 80\%). While data collected six months after graduation is limited to showing short-term graduate destinations, as was discussed earlier, because of their potential impact on subsequent employment, first destinations remain an important indicator of future trajectories.

Our primary interests in this paper are the early career destinations of STEM graduates although, where appropriate, we compare these to the destinations of non-STEM graduates. Defining STEM subjects can be problematic and some broad definitions include subjects with relatively little scientific content. In the absence of a consensus (see Select Committee on Science and Technology 2012) we have adopted the widely-used UK universities admissions authority (UCAS) definition. A full list of UCAS STEM subjects is provided at the end of this paper. ${ }^{1}$

We focus on the five main STEM subject groups listed below, along with their main constituent subjects: 
- Biological Sciences: including biology, sports science, and psychology.

- Physical Sciences: including chemistry, physics, and physical geographical sciences.

- Mathematical Sciences: including mathematics.

- Computing Sciences: including computer science

- Engineering Sciences: including civil, mechanical, and electronic and electrical engineering.

We analyse occupational destinations according to the following widely used criteria:

\section{STEM sector employment}

Deciding whether or not a graduate is employed in a highly skilled STEM sector job is problematic and sometimes arbitrary (Mellors-Bourne et al. 2011). With this caveat in mind, we have adopted the classification used by United Kingdom Commission for Education and Skills (2011) which uses the criteria of whether an occupation has a high proportion of graduates, a high proportion of STEM-degree holders and a high proportion of STEM-degree holders among graduate entrants. The list below shows the UKCES (2011) classification of highly skilled STEM jobs and the corresponding UK Standard Occupation Classification (SOC) 2000 3-digit occupational codes.

SOC code Highly skilled STEM occupations

$112 \quad$ Production Managers

$121 \quad$ Managers in Farming, Horticulture, Forestry and Fishing

211 Science Professionals

$212 \quad$ Engineering Professionals

213 Information and Communication Technology Professionals

$221 \quad$ Health Professionals

$232 \quad$ Research Professionals

$242 \quad$ Business and Statistical Professionals

243 Architects, Town Planners, Surveyors

$311 \quad$ Science and Engineering Technicians

312 Draughtspersons and Building Inspectors

$313 \quad$ IT Service Delivery Occupations

$351 \quad$ Transport Associate Professionals

$353 \quad$ Business and Finance Associate Professionals

$355 \quad$ Conservation Associate Professionals

\section{Graduate employment}

As participation in higher education has increased, so has the range of what might be considered to be graduate jobs. To help address this issue Elias and Purcell (2004) propose a five-category classification of graduate destinations:

- 'Traditional': Established professions requiring degrees, such as solicitors, secondary school teachers and chemists. 
- 'Modern':

- 'New':

- 'Niche':
Newer professions that graduates have entered since university expansion in the 1960s, such as computer programmers and journalists.

New or expanding areas where the route into the professional area has recently changed so that it is now via an undergraduate degree, for example: physiotherapists and probation officers.

Occupations where the majority of post holders are not graduates, but where there are stable or growing specialist niches which require higher education skills. For example: nurses, retail managers.

- 'Non graduate': Occupations that do not fall into any of the above categories.

The key distinction for many of our analyses in this paper is that between graduate and nongraduate destinations. The first of Elias and Purcell's four categories - 'traditional', 'modern', 'new' and 'niche - constitute graduate employment and the fifth, non-graduate employment. Using this classification, graduate employment is defined as most occupations that fall into SOC categories 1-3 (Managerial, Associate/Professional and Technical); while non-graduate employment largely comprises SOC categories 4-9 (Administrative and Secretarial, Personal Service, Sales and Customer Service, Machine Operatives and Elementary Occupations). A full list of occupational categories and their link to (non)graduate employment can be found in Elias and Purcell (2004).

\section{Findings}

The findings are presented in two sections: general destinations (whether graduates enter employment, remain in education or are unemployed) and destinations within the labour force for those who gain employment after graduation. Detailed findings are included for the main STEM subject groups (namely the engineering, computing, physical, mathematical and biological sciences) but, where appropriate, comparisons are made with the destinations of non-STEM graduates. Because of limitations of space, we focus only on the destinations and subject areas that are most relevant to current debates and where patterns are most striking. A full report that includes data for all subject areas is available from the authors. Unless otherwise stated, the data presented here refer to home-domiciled, full-time, first-degree graduates studying at higher education institutions in the UK.

\section{General destinations of recent graduates}

Figure 1 shows the general destinations of graduates (STEM and otherwise) who left university between 1994/5 and 2010/11. The destinations are categorised as follows: those who were in employment, those who were pursuing further study and those who were 
unemployed. ${ }^{2}$ Around half of all graduates went into some form of employment, regardless of their degree subject, and the patterns were relatively stable across this time period. The slight dip in the proportion entering employment between 2006/07 and 2007/08 may be a consequence of the UK economy being in recession. Trends for those entering further study or being unemployed were also reasonably flat. This indicates that while the numbers of graduates leaving university may have increased, the proportion taking different employment or educational routes after graduation has hardly changed over the period considered. It is worth noting that, over the period as a whole, around $10 \%$ of all first-degree graduates were unemployed six months after graduation. What is evident from these data is the relative stability of graduate destinations over a decade and a half, despite considerable changes in both the higher education sector and the UK economy.

Figure 1: First destinations of graduates, 1994/5-2010/11, all subjects (percentages)

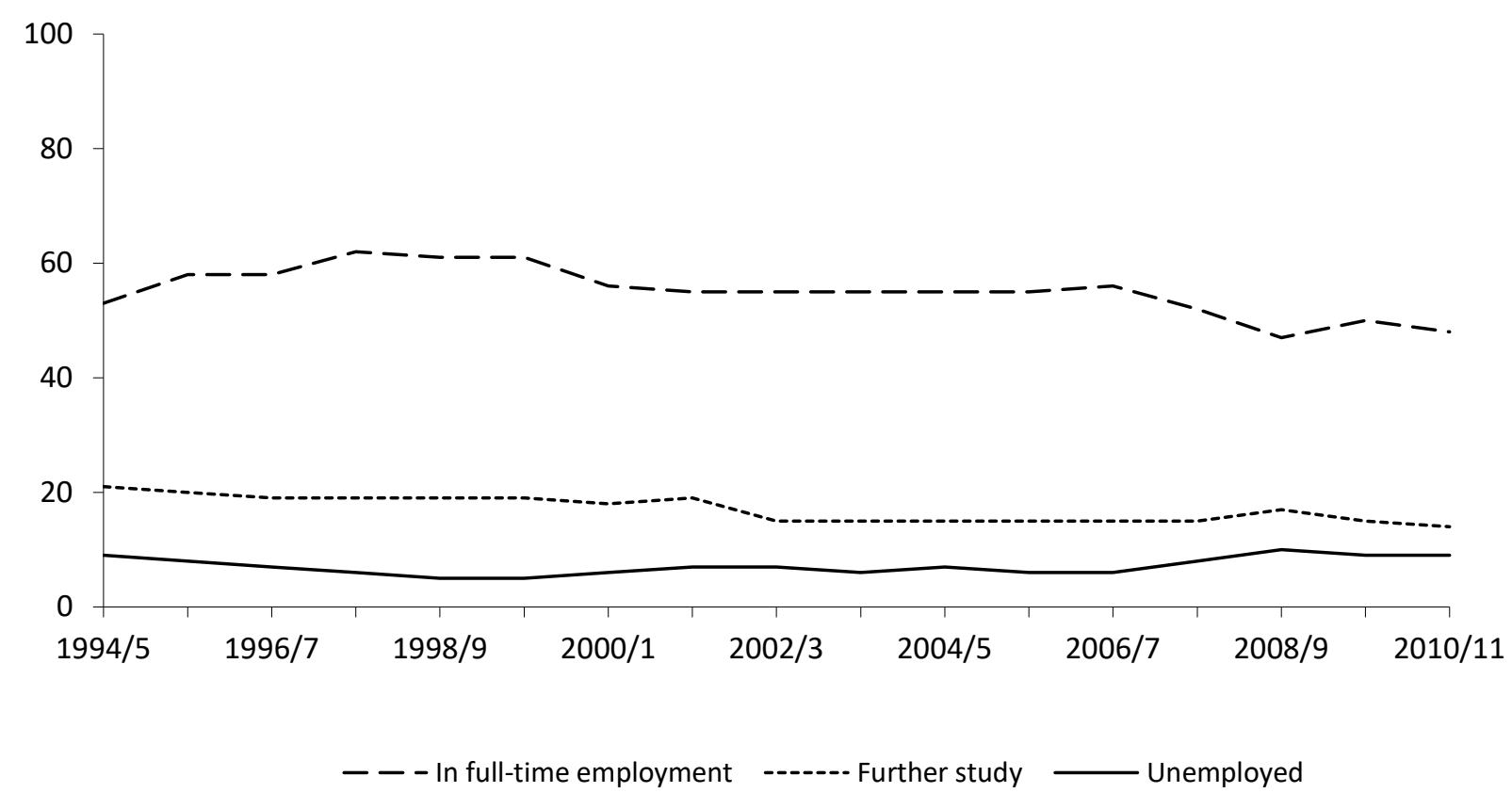

As noted earlier, although concerns have been raised about graduate destinations in general, particular attention has been paid to the outcomes for STEM students. For example, as can be seen in Figure 2, in the engineering sciences the majority of graduates (57\% in 2010/11) entered full-time employment, while around 13\% remained in further study and a slightly smaller proportion were unemployed. The situation for computer science graduates was very similar. The levels of unemployment among these two key groups of STEM graduates were largely comparable to the levels for graduates as a whole but a slightly lower proportion of engineers and computer scientists entered further study and a correspondingly higher percentage gained employment. 
Figure 2: First destinations of engineering science graduates, 1994/5-2010/11.

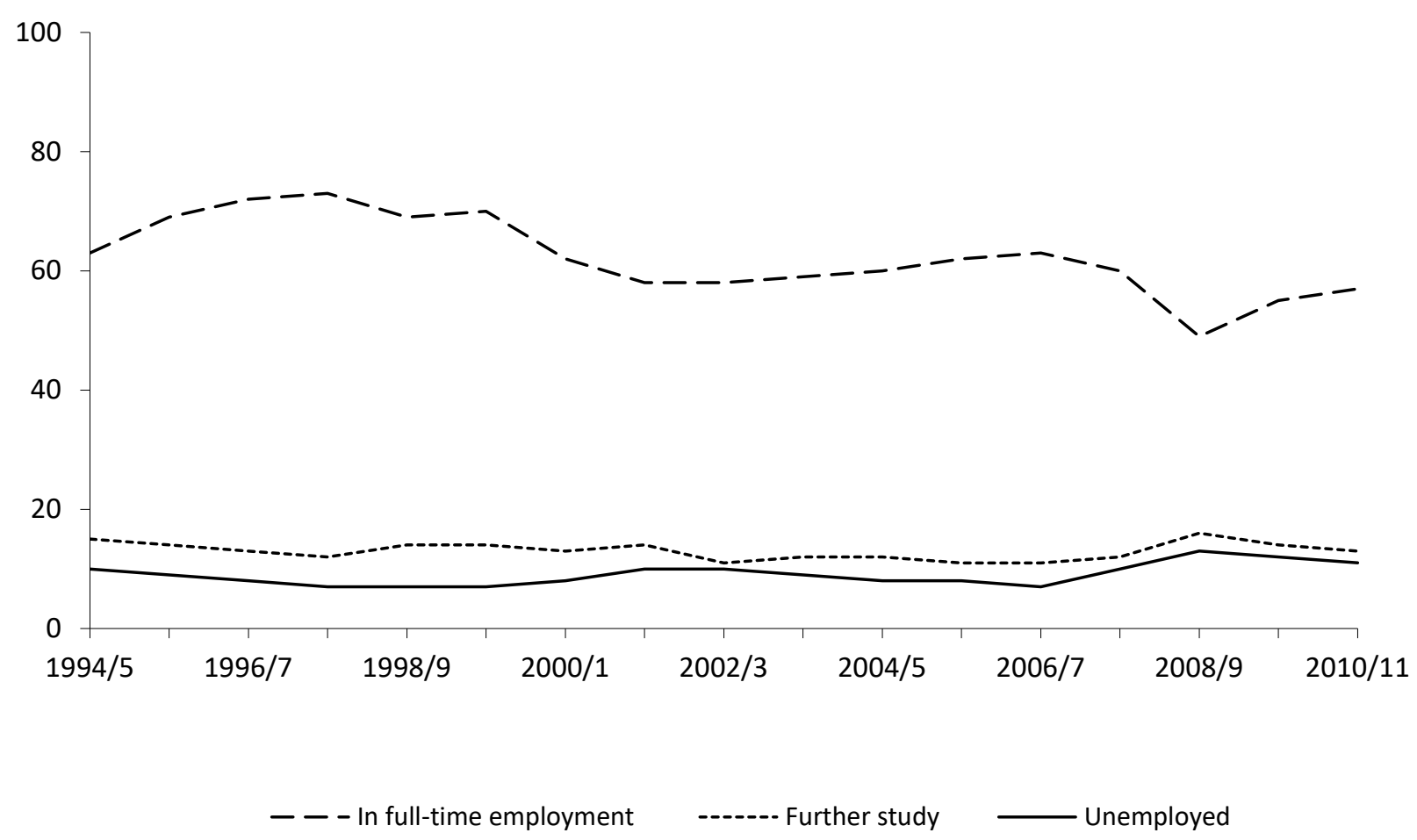

Somewhat different trends can be seen in the other main STEM groups (the biological, physical and mathematical sciences) where relatively high proportions of graduates remained in education after graduation. Figure 3 shows the patterns for the physical sciences. Over the period considered here, just under half of these students entered full-time employment and slightly less than one-third remained in education. Levels of unemployment for physical science graduates were only slightly lower than the levels for all graduates and were very similar to those from more vocationally-orientated degrees such as the engineering sciences.

It is worth highlighting the relatively high proportions of physical and mathematical science graduates who remained in education after graduation (compared with less than $20 \%$ of graduates overall). As is discussed later in this paper, this may be partially related to the length of their degrees, which are slightly more likely to be studied over a three year period than the four year length that is more common in subject areas such as the engineering sciences. Note also that unemployment figures fluctuated only slightly across the period considered, averaging around $8 \%$ of graduate destinations. This fact, combined with what appears to be a stable relationship between rates of employment and levels of postgraduate study, suggests that for this group of graduates pursuing further study may have been an alternative, or prerequisite, to entering the labour market. 
Figure 3: First destinations of physical science graduates, 1994/5-2010/11.

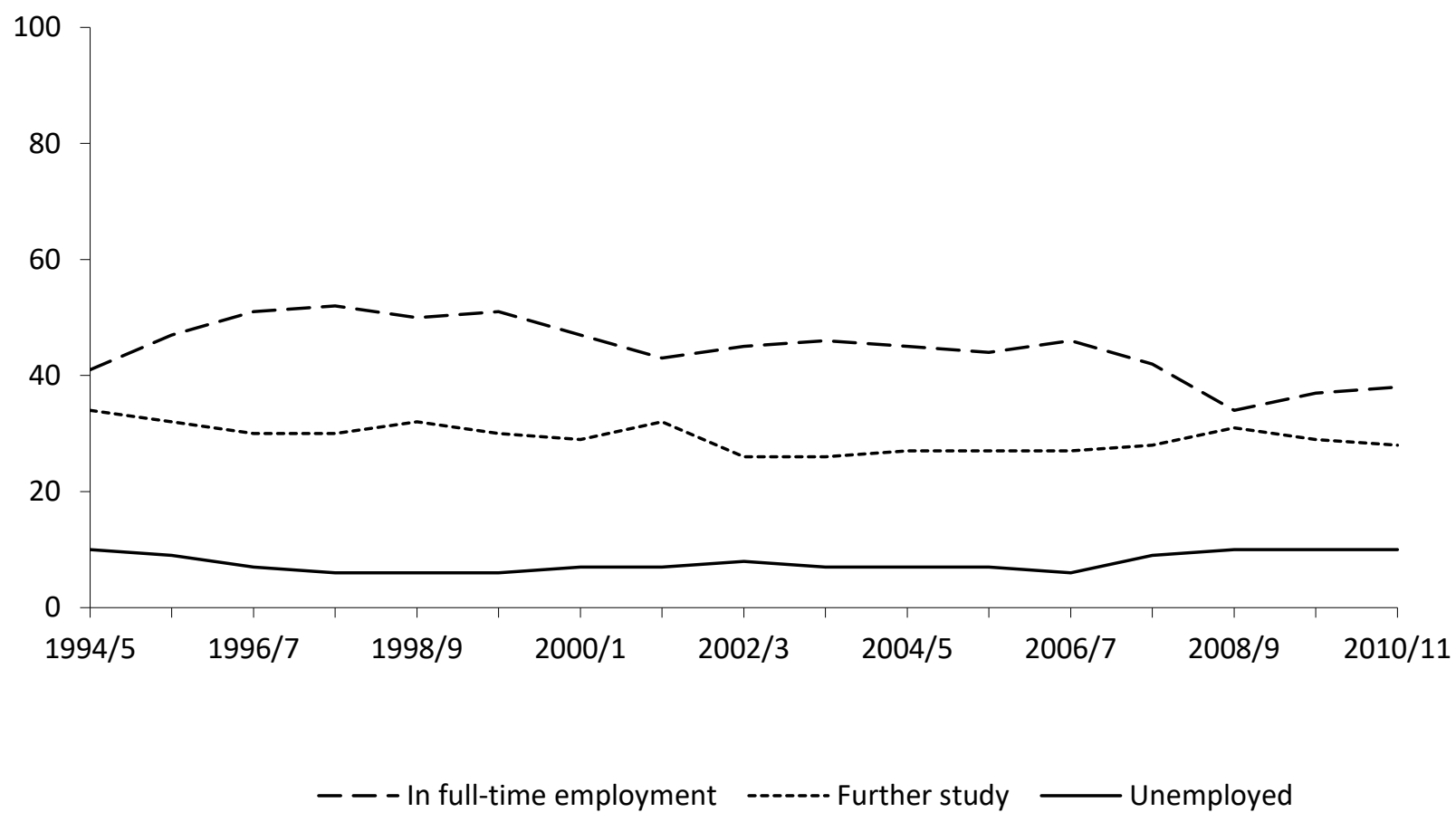

Table 1 gives the first destination data for the full range of degree subject areas for 2010/11, the most recent year for which comparable data were available. ${ }^{3}$ The most common sixmonth destination for graduates from all subject areas was full-time employment but the employment rates were relatively similar for STEM subjects (52\%) and non-STEM subjects (46\%). Employment rates among graduates in arts and humanities subjects were very similar to those who had graduated with traditional science subjects. For example, historical and philosophical studies graduates had almost the same employment rate as their peers who had studied chemistry. Unsurprisingly, in more vocationally oriented subjects, such as the medical sciences, very high proportions of graduates entered employment. Whereas subjects like law and psychology, where postgraduate training is often necessary before professional qualifications are awarded, had high levels of entry to programmes of further study. As can be seen from the table, apart from medicine and dentistry, there is no evidence of a clear difference between the employment rates of graduates from STEM and non-STEM subjects. The levels of further study (both full- and part-time) between the STEM and non-STEM groups were also very similar. The proportion of non-STEM graduates who were unemployed was 2 percentage points lower than STEM graduates, at $10 \%$ and $8 \%$ respectively. While this difference is reasonably large proportionally, as we show later, it masks the considerable variation within the STEM and non-STEM subject groups. 
Table 1: Destinations of UK-domiciled, full-time graduates by subject area, 2010/11

\begin{tabular}{|c|c|c|c|c|}
\hline & $\begin{array}{l}\text { In full-time } \\
\text { employment }\end{array}$ & $\begin{array}{l}\text { Work and } \\
\text { further } \\
\text { study }\end{array}$ & $\begin{array}{l}\text { Further } \\
\text { Study }\end{array}$ & Unemployed \\
\hline All STEM subjects & 52 & 8 & 15 & 8 \\
\hline All non-medical STEM subjects & 50 & 8 & 15 & 9 \\
\hline Medicine and dentistry & 90 & 4 & 4 & 0.07 \\
\hline Subjects allied to medicine & 62 & 8 & 9 & 6 \\
\hline Biological Sciences & 38 & 9 & 20 & 9 \\
\hline Biology & 31 & 8 & 29 & 11 \\
\hline Psychology & 39 & 10 & 17 & 8 \\
\hline Agriculture and related & 58 & 6 & 10 & 8 \\
\hline Physical Sciences & 38 & 8 & 28 & 10 \\
\hline Chemistry & 35 & 7 & 35 & 8 \\
\hline Physics & 32 & 9 & 37 & 11 \\
\hline Mathematical Sciences & 38 & 15 & 24 & 9 \\
\hline Computer Science & 54 & 5 & 10 & 15 \\
\hline Engineering and Technology & 57 & 6 & 13 & 11 \\
\hline Mech. engineering & 62 & 6 & 13 & 9 \\
\hline Architecture, building \& planning & 54 & 10 & 10 & 10 \\
\hline All Non-STEM subjects & 46 & 8 & 14 & 10 \\
\hline Social Studies & 45 & 9 & 14 & 10 \\
\hline Law & 30 & 13 & 32 & 8 \\
\hline Business \& admin studies & 54 & 10 & 7 & 11 \\
\hline Mass comms \& documentation & 51 & 4 & 6 & 12 \\
\hline Media Studies & 49 & 4 & 6 & 13 \\
\hline Languages & 40 & 9 & 21 & 9 \\
\hline Historical/ Philosophical studies & 36 & 9 & 24 & 9 \\
\hline Creative arts and design & 46 & 7 & 9 & 12 \\
\hline Education & 58 & 6 & 9 & 5 \\
\hline Combined subjects & 40 & 7 & 16 & 10 \\
\hline All subjects & 48 & 8 & 14 & 9 \\
\hline
\end{tabular}

Percentages do not add up to $100 \%$ because some destination types (e.g. other) have been omitted.

In the context of the extended length of some STEM degree programmes (as discussed below), it is interesting to see that more than one-third of chemistry and physics graduates remained in education rather than entering the work force upon graduation. Their trajectories are different to those of engineering science graduates (a subject group that also tends to offer extended length degree programmes) who were more likely to go directly into employment.

So far the analysis suggests that there are three distinct trajectories for graduates from different STEM disciplines: 
1. Almost all graduates in more vocational STEM subjects such as medicine and dentistry entered employment directly after graduation. Ninety percent of medicine and dentistry graduates were in full-time employment six months after graduating and a further $4 \%$ combined work and study. Of the remainder only $4 \%$ were studying fulltime and less than $0.1 \%$ were unemployed.

2. More than half of graduates in the engineering or computer sciences entered fulltime employment. For example, in 2010/11, 62\% of mechanical engineering graduates were employed full-time and another $6 \%$ worked while continuing to study. While the computer sciences had relatively high proportions of graduates entering employment, they also had one of the highest rates of unemployment.

3. Within disciplines such as the physical, biological and mathematical sciences, relatively high proportions of graduates remained in education and undertook some form of further study (either full or part-time). With the exception of psychology, between just under one-quarter and just over than one-third of graduates in these subjects continued with their studies after graduation and another $7 \%$ to $15 \%$ combined work with further study. Physics had the highest level of postgraduate participation with $46 \%$ of graduates studying full- or part-time.

\section{Graduate unemployment}

Long-term trends in graduate unemployment for selected subjects are presented in more detail in Figure 4. These data include only those who are actively seeking work and show that there were few differences in the unemployment rate between some of the main STEM and non-STEM subject areas. For example, over the period studied, around $8 \%$ of language graduates were unemployed six months after graduation, compared with approximately $10 \%$ of engineers. Unemployment rates for computer science graduates were among the highest of all subject areas; $15 \%$ of computer science graduates graduating in 2010/11 were unemployed six months after graduation. There is little evidence to suggest that the unemployment rates of graduates in several STEM shortage areas were substantially lower than those of graduates in non-STEM subjects. 
Figure 4: Proportion of graduates who were unemployed 6 months after graduation, selected subjects $1994 / 5$ to $2010 / 11$.

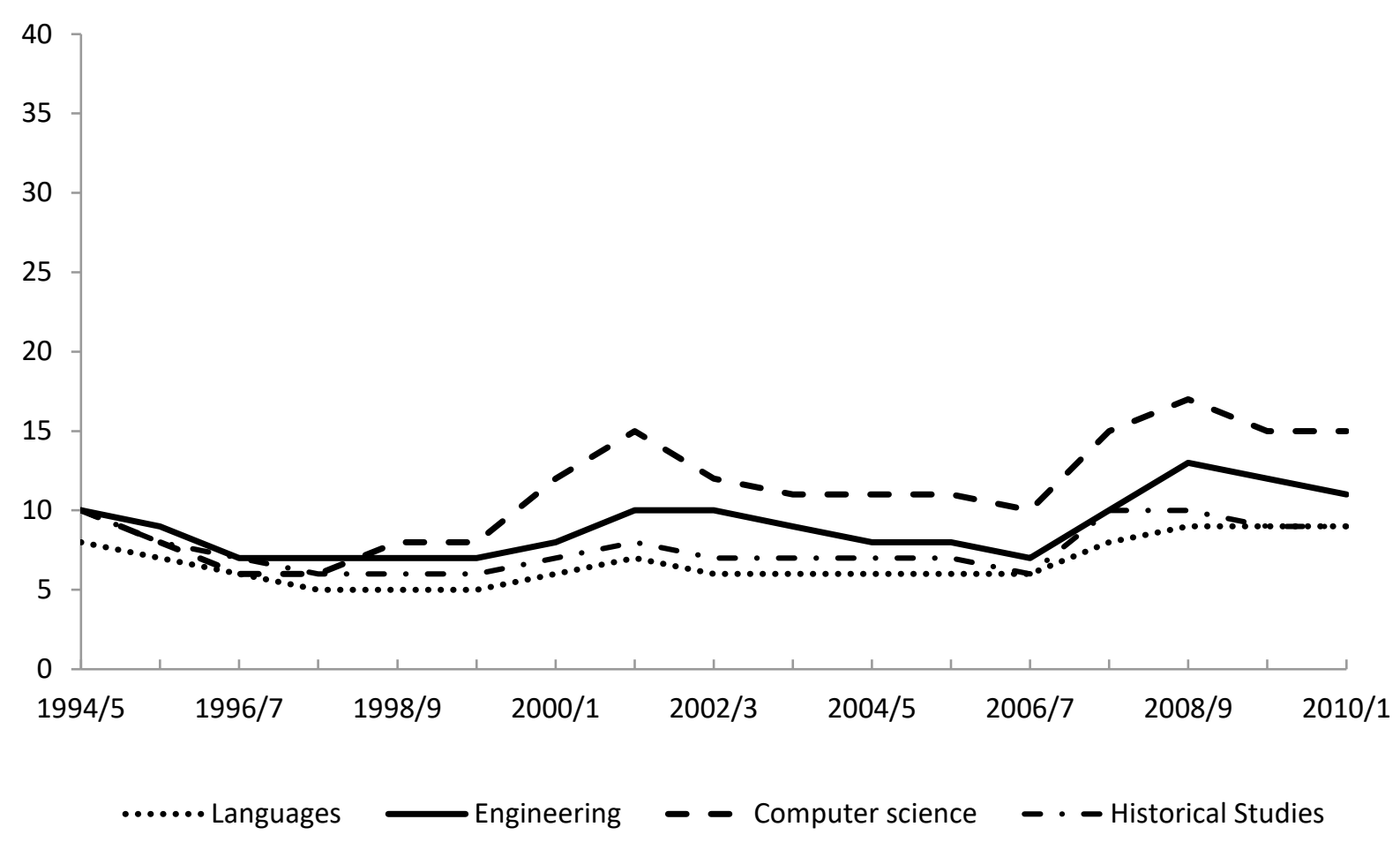

A number of findings have emerged from this first stage of analysis and are summarised here:

- Patterns of early graduate destinations have remained relatively stable between 1994/5 and 2010/11. This is despite the number of students entering university almost doubling since 1994/5 and dramatic changes in the economy.

- Graduates from the engineering and computer sciences were more likely to enter employment upon finishing university than those from the other STEM groups considered here, but did not have substantially higher employment rates than graduates as a whole. It is certainly not the case that studying any STEM subject guarantees students a better than average chance of getting a job. Even the STEM subject groups with the best employment rates did not offer a very large labour market advantage for graduating students (with the exception of those in medicine and dentistry).

- Relatively high proportions (often around a quarter) of graduates from the biological, mathematical and physical sciences remained in education following completion of their first degree. This might suggest that, for many students in these subject areas, three years of undergraduate study was insufficient to gain employment in their chosen fields, or at least was perceived to be insufficient.

- Relatively high proportions of engineering and computer science graduates (in some years more than $10 \%$ ) were unemployed six months after graduation. This is particularly 
interesting given the context of shortage accounts in these subject areas, and this issue is returned to later in this paper.

\section{Employment destinations of STEM graduates}

Data on employment destinations were analysed over the nine-year period between 2002 and $2010 .{ }^{4}$ Variations in graduate-level and highly skilled STEM employment, as well as the occupational destinations of STEM and non-STEM graduates more generally, are examined below.

\section{Graduate-level employment}

Figure 5 shows the proportion of graduates from selected subject areas who entered 'graduate-level' employment (as defined by Elias and Purcell, 2004). The graph shows data from a selection of STEM and non-STEM subjects, chosen to best illustrate the variation between subject groups.

Figure 5: Percentage of students entering employment who gain 'graduate' type jobs, selected subject areas, 2002-2010/11

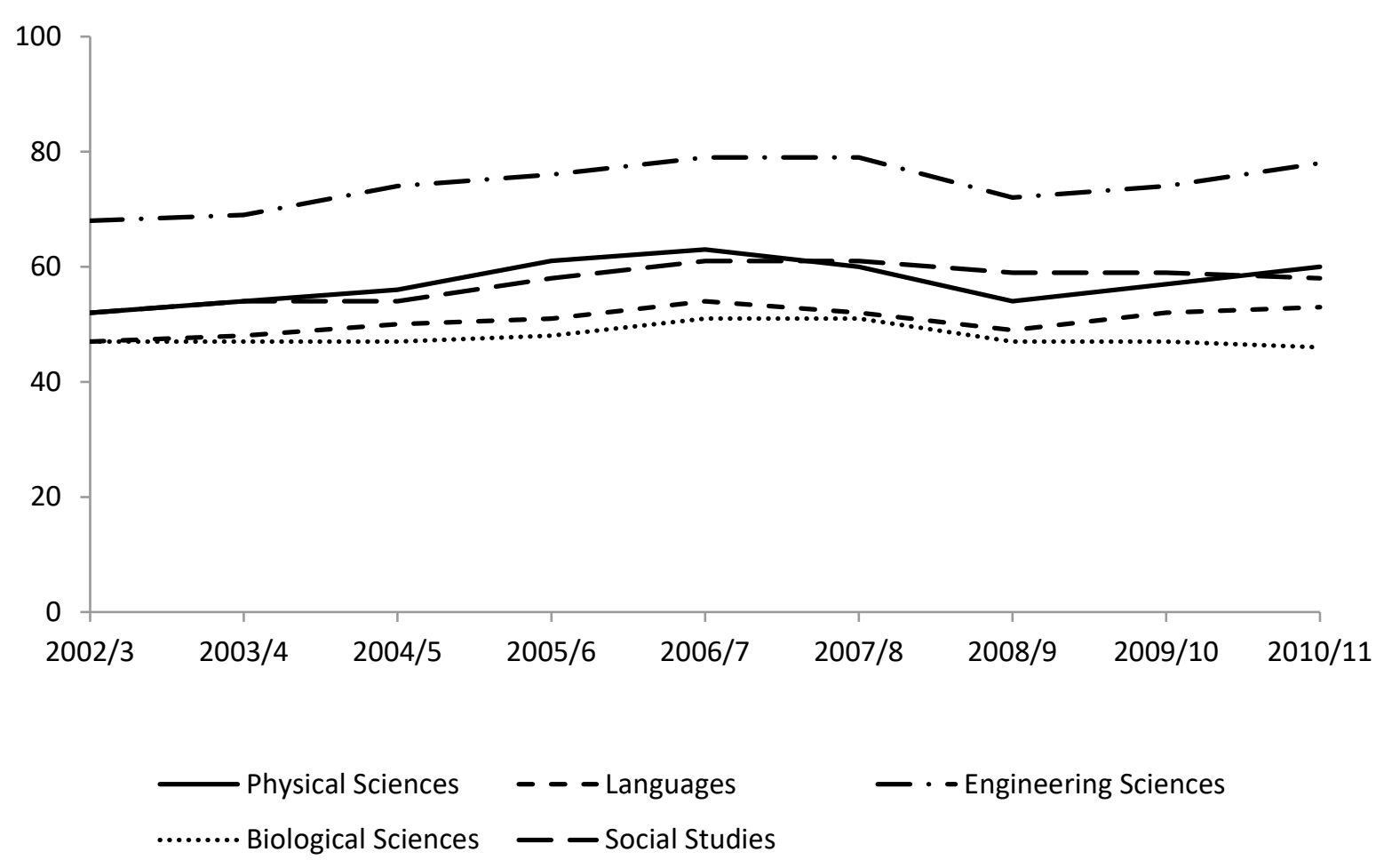

Of those who enter employment, between two-thirds and three-quarters of engineering science graduates enter 'graduate-level' jobs, the highest proportion of all the main STEM groups (excluding medicine and dentistry). As can be seen in Figure 5, this figure is noticeably higher than the rates for the physical and biological sciences, languages and social studies, which have much more similar levels graduate-level employment. 
Over the period considered, similar proportions of physical science and social studies graduates entered 'graduate' jobs, with biological sciences graduates having slightly lower entry rates. With the exception of engineering graduates there appears to be no major differences between the proportion of students entering 'graduate' type jobs from among the STEM and non-STEM subjects examined here. These data show that it is not only the case that, as a group, STEM graduates do not have a substantially higher level of employment than non-STEM graduates; neither do they have much greater chances of obtaining a graduatelevel job. While graduates from some subject areas - such as the engineering sciences - have better than average prospects in this respect, graduates in the biological sciences actually fare slightly worse than their peers with languages and social studies degrees. Variation between STEM subjects is, in some respects, greater than the difference between STEM and nonSTEM subjects at the aggregate level.

\section{Highly skilled STEM occupations}

Figure 6 shows the proportion of employed graduates who found work in 'highly skilled' jobs in the STEM sector. Around one-third of non-medical STEM graduates (i.e. excluding those who studied medicine and dentistry) who entered employment were working in these highly skilled jobs six months after graduation, while the figure for non-STEM graduates was around $12 \%$.

However, there are important variations in the destinations of students from different STEM subject areas. On average, between 55 and $60 \%$ of engineering science graduates who gained employment were working in highly-skilled STEM jobs but for biological science graduates the proportion was not much more than $16 \%$. This is only slightly higher than the proportion of graduates from non-STEM subjects and in some years was actually lower than the proportion of social studies graduates gaining highly skilled STEM positions. There is clearly considerable variation in the extent to which different STEM subjects supply the highly skilled STEM graduate workforce. In terms of the proportion of employed graduates entering these kinds of jobs some STEM subjects, notably the biological sciences, appear to be worse than some of the non-STEM subjects, and are not much better than the overall average figure for non-STEM subjects combined. It is unsurprising that STEM graduates as a whole find it easier to obtain highly skilled STEM occupations than do their counterparts with non-STEM degrees. What is more remarkable is the similarity in the proportion of non-STEM graduates entering these kinds of occupations when compared with graduates from some STEM subject groups, such as the biological sciences. 
Figure 6: Proportion of graduates gaining employment, entering highly-skilled STEM occupations, by subject group, 2002-2010

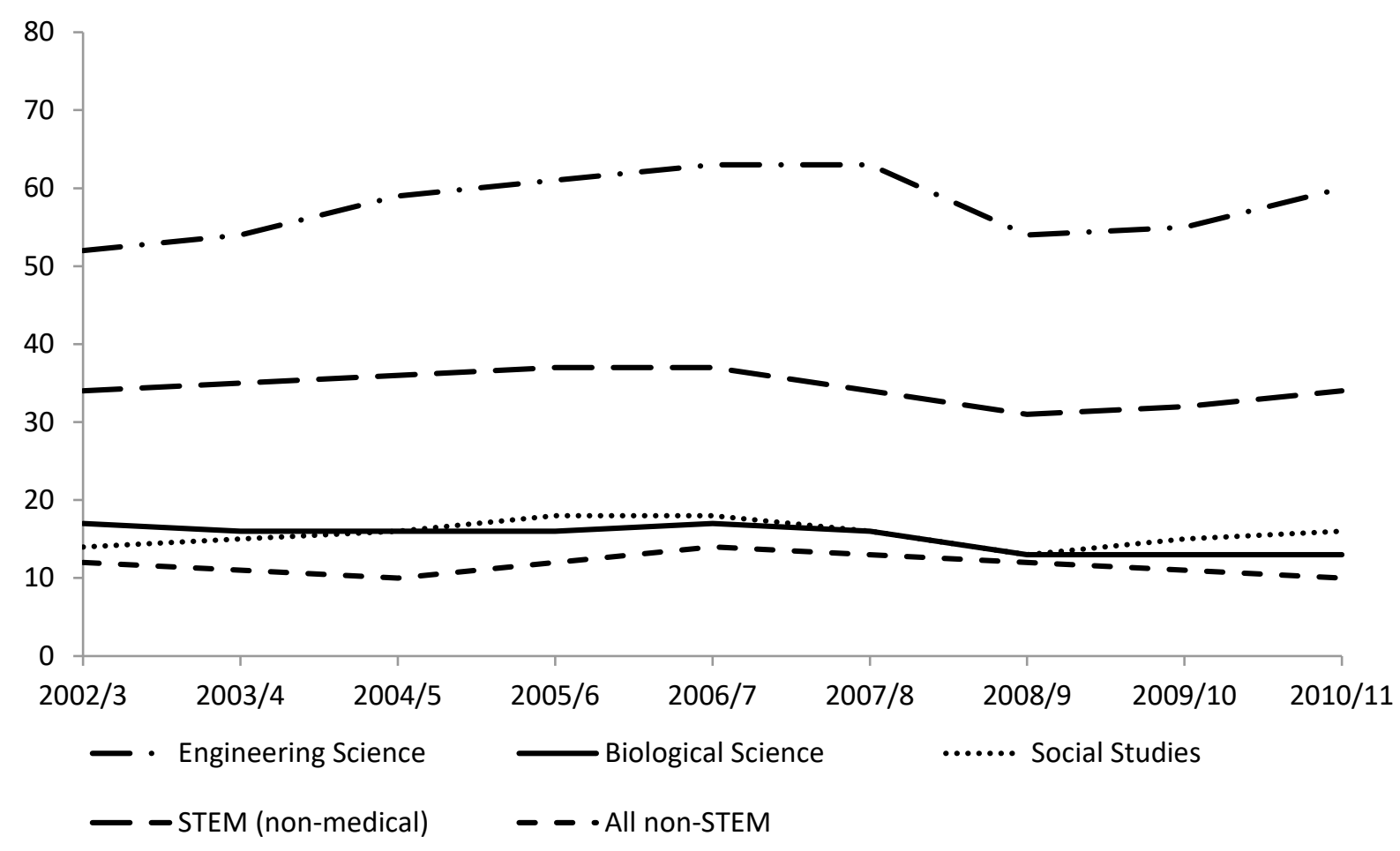

\section{Socio-occupational categories}

This section shows in more detail the types of jobs undertaken by recent graduates. Across all subject areas, approximately half of graduates entering employment gained positions in either

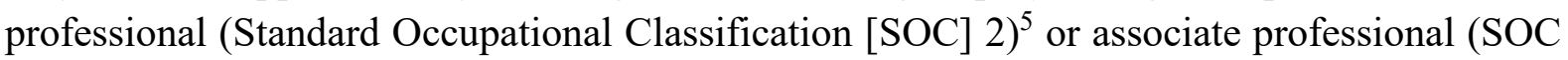
3 ) occupations (Figure 7). This proportion has remained relatively stable from 2002/03 to 2010/11 but since 2005/06 SOC 3 destinations have slightly outnumbered SOC 2 jobs. This gap has widened slightly between 2008/09 and 2010/11 but it is too soon to establish whether this is the beginning of a long term trend or a fluctuation associated with the economic downturn.

There has been a steady decline in the proportion of graduates entering administrative and secretarial occupations (SOC 4) which fell from 16\% in 2002 to 8\% in 2010. Between 2007/8 and 2008/9, sales and customer service occupations (SOC 7) moved above this group to become the third largest employment group, accounting for around 13\% of all recent graduates who entered employment between 2008/9 and 2010/11. 
Figure 7: Largest four occupational group destinations, all graduates entering employment, 2002-2010

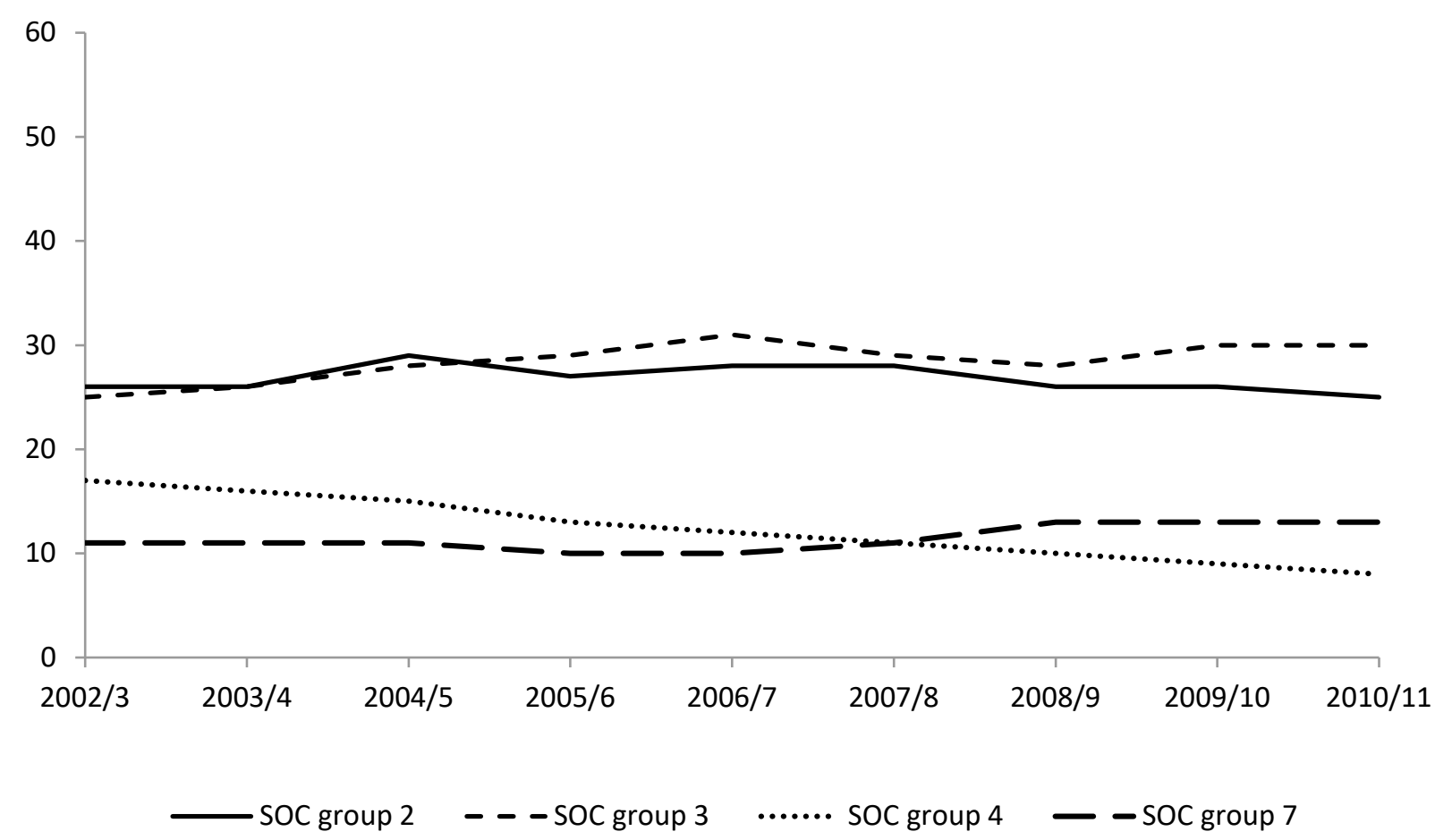

Figure 8 shows the main occupational group destinations for graduates from all non-medical STEM subject areas. There are a number of similarities between these data and those for all subjects shown in Figure 7, above. The four largest occupational groups (SOC 2, 3, 4 and 7) are the same as for all graduates taken together, suggesting that the type of jobs that nonmedical STEM graduates take are similar to other employed graduates. The changes over time are also similar. The same gradual decrease in SOC 4 occupations can be seen alongside a slight rise in SOC 7 jobs and, although there is some fluctuation, the proportion of those employed in SOC 2 and SOC 3 jobs is relatively stable over the nine year period.

There are several differences between the data for non-medical STEM graduates and those for all graduates, however, although none of these differences are particularly large. Firstly, there is a higher proportion of non-medical STEM graduates gaining jobs in the SOC 3 occupational categories. For example, in 2010/11 35\% of non-medical STEM graduates entered SOC 3 occupations compared with $30 \%$ of all graduates (see Figure 7, above). Secondly, the proportion of non-medical STEM graduates in SOC 4 occupations is generally slightly lower over the period studied but figures for the last two years of data are very similar to those for all graduates. There is little difference between non-medical STEM graduates and the overall picture for SOC 2 destinations. For example, in 2010/11 28\% of non-medical STEM graduates entered SOC 2 occupations compared with $25 \%$ of all graduates. SOC 7 occupations are only slightly less common for non-medical STEM graduates than they are for the graduate workforce as a whole. 
Yet again, the data show very little to distinguish the career prospects of non-medical STEM graduates from their graduating peers with non-STEM degrees. Their main advantage is in securing SOC 3 occupations, where they have some advantage over other students. However, in relation to the other three most popular occupational group destinations, any advantage they have is marginal.

Figure 8: Largest four occupational group destinations, all non-medical STEM graduates entering employment, 2002-2010

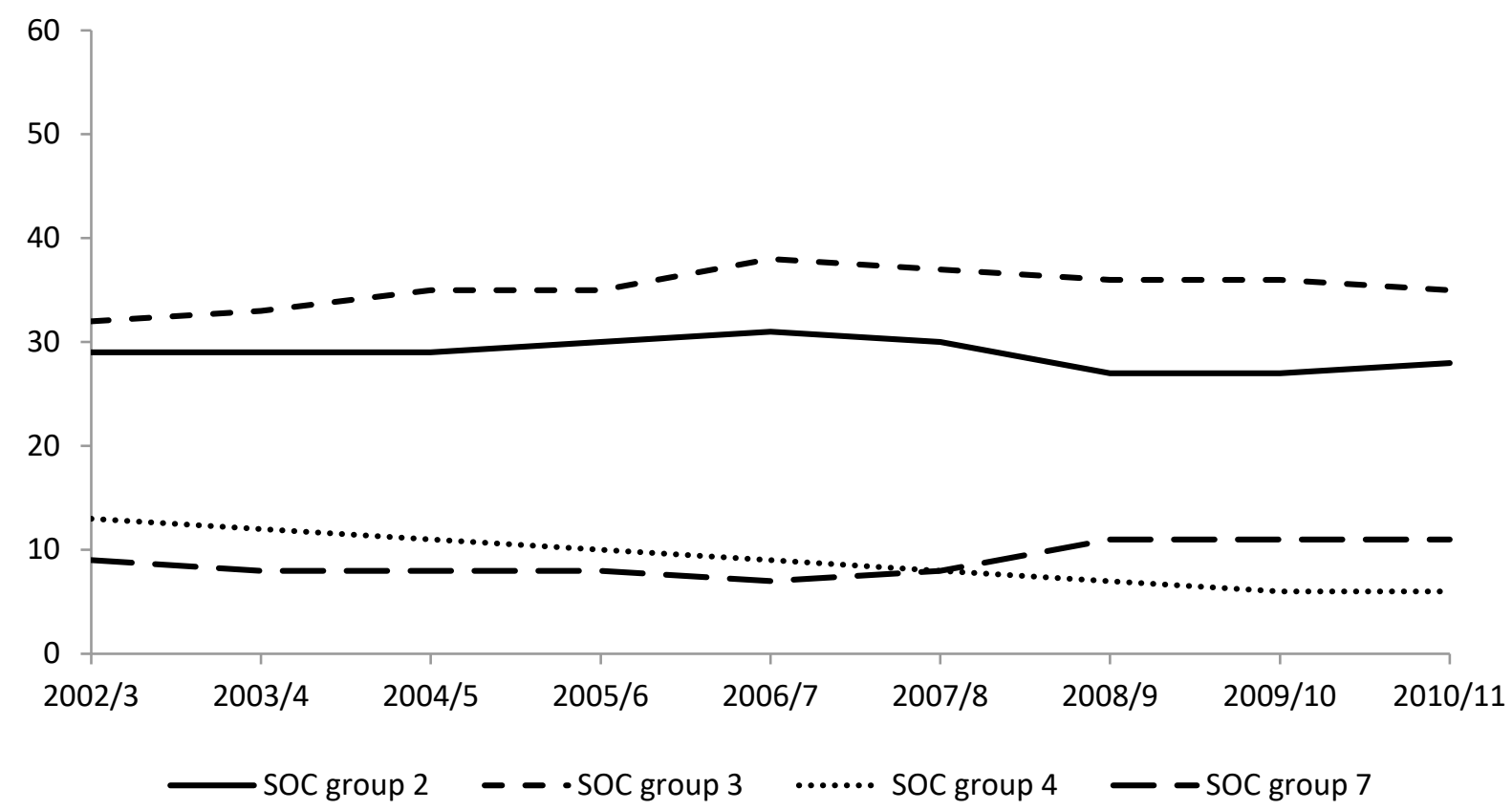

There is some variation in occupational group destinations between the different STEM subject areas. Data on biological sciences graduates illustrate this clearly. Unlike the data for all graduates and that for all STEM graduates, SOC 6 (Caring personal service) occupations replace SOC 4 occupations in the four most common employment destinations for these students (Figure 9). There is a considerable gap between the proportion of employed graduates gaining SOC 3 jobs and the proportion in SOC 2 occupations; far larger than for either all graduates or all STEM graduates in employment. There has also been a gradual decline in the proportion of biological science graduates entering SOC 2 occupations, from $19 \%$ in 2002 to $13 \%$ in 2010 . The proportion taking up SOC 7 occupations, in contrast, rose from $12 \%$ in $2006 / 7$ to $18 \%$ in $2010 / 11$. In 2010 more biological science graduates held SOC 6 or 7 jobs than entered SOC 2 employment. The biological sciences have relatively weak employment outcomes, not only compared to other STEM subject groups but also in comparison to some non-STEM subjects and subject groups. The extent of the variation in destinations between STEM subjects and subject groups means that discussions focussing on STEM subjects as a homogeneous group are not particularly helpful. There is evidence that some STEM groups, such as the engineering sciences discussed below, have better than average employment outcomes in some respects but subject groups, such as the biological 
sciences, have poorer outcomes than many non-STEM subjects, even in terms of getting into STEM-related positions.

Figure 9: Largest four occupational groups, biological science graduates entering employment, 2002-2010

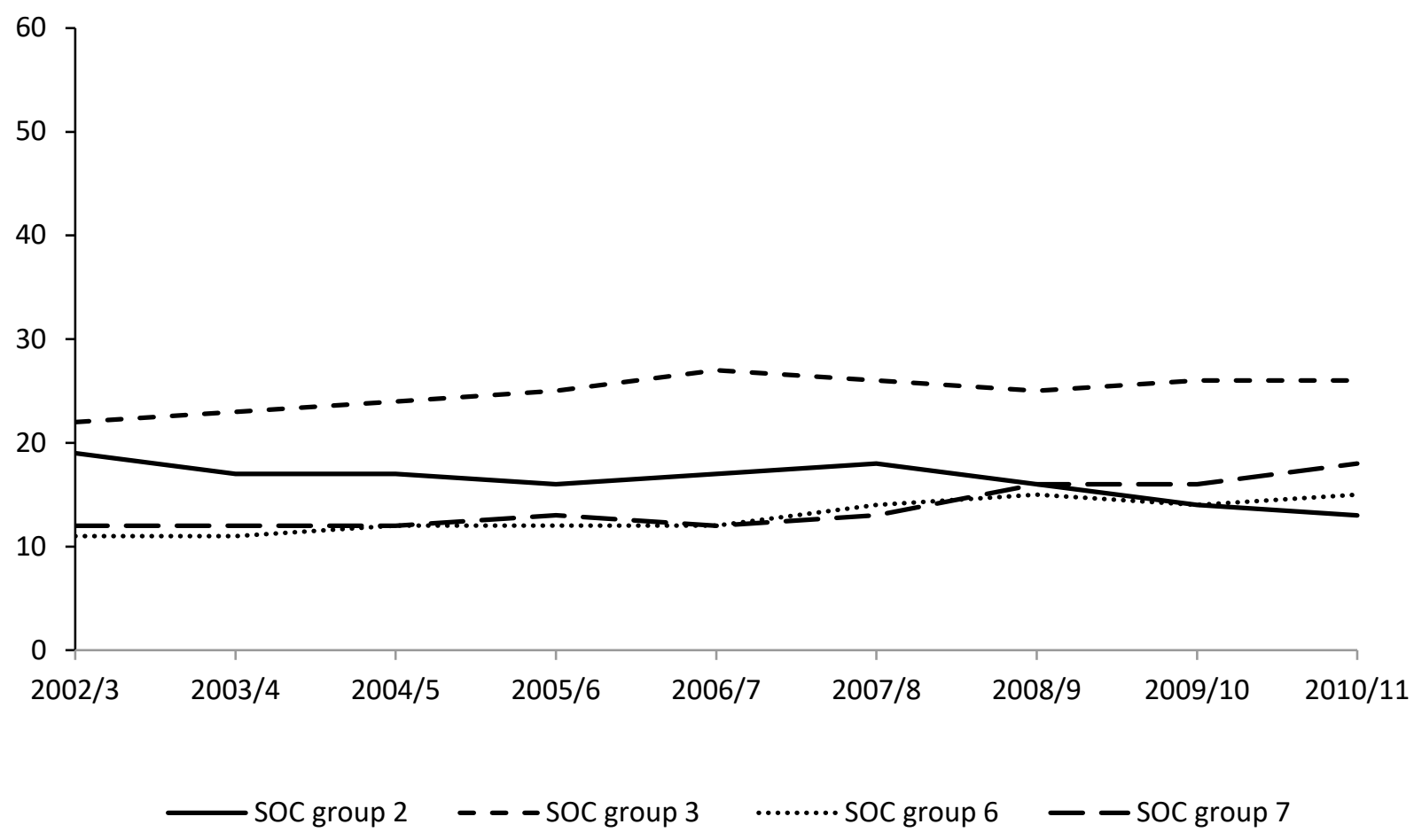

As can be seen in Figure 10, the pattern is very different for the engineering sciences. It is first important to note that the four occupational groups taking the largest proportion of employed graduates from the engineering sciences differ from the biological sciences, STEM subjects overall, and all graduate employment. While employed graduates and employed STEM graduates as a group tend to go into SOC 2, 3, 4 and 7 occupations, biological science graduates mainly find employment in occupational groups SOC 2, 3, 6 and 7, and engineering science graduates find jobs in groups 2, 3, 7 and 9. SOC 9 positions include elementary occupations, such as cleaners or traffic wardens, while SOC 6 occupations include personal service roles, such as care assistants or nursery nurses. The differences in Figures 7 to 10 merely reflect this.

The majority of engineering science graduates who found employment (around 54\% from the 2010/11 cohort) entered SOC 2 occupations. The proportion of graduates entering this occupational group declined slightly between 2007 and 2008, was relatively stable between 2008 and 2009, but has increased between 2009 and 2010. These fluctuations were relatively large and may be related to changes in the economy over this period. What is clear, however, is that engineering science graduates have better chances than most other students of obtaining high status professional positions shortly after graduation. As can be seen in Figure 10 , these are by far the most common type of occupations for engineering graduates, and the 
graph shows a large gap between the proportion of employed graduates entering SOC 2 occupations and the next largest group of SOC 3 jobs. Only around 15\% of engineering science graduates entering employment go into SOC 3 occupations. This is in contrast to general graduate employment, which showed a similar level of SOC 2 and SOC3 employment and non-medical STEM graduate employment in general, which was more likely to be in SOC 3 than SOC 2 jobs. Engineering, then, stands out as the non-medical STEM subject group offering the best prospects for entry into higher level professional careers.

At the 'lower' end of the occupational scale (i.e. occupational groups SOC 7 and 9), however, the proportion of engineering science graduates is very close to that for the general graduate population (e.g. $11 \%$ of graduates in SOC 7 jobs in $2009 / 10$ is close to the figure for all graduates) and there are also relatively high unemployment rates among this group (see Figure 4 above). This perhaps points to two very different types of destinations for engineering graduates, with just over a quarter (slightly more than half of the half who go into full-time employment) working full-time in high status SOC 1 or 2 occupations, another quarter going into lower status full-time jobs (some of which require degrees), and the remainder continuing their studies, working part-time, registering as unemployed or engaged in other activities. ${ }^{6}$

In terms of gaining graduate-level employment, only slightly more than one-third of engineering graduates gain this kind of work. Over $70 \%$ of those who secure full-time work enter graduate professions (see Figure 5, above) but only $50 \%$ to $60 \%$ of engineering graduate enter full-time occupations (see Figure 2). So while engineering graduates have a considerable advantage over most of their peers in terms of both gaining employment and being employed in high status and graduate positions, only a minority of engineering students find themselves in professional careers six months after graduating. These figures have been relatively stable for some time and fit uncomfortably with 'crisis' accounts of chronic shortages of STEM - and particular engineering - graduates.

Figure 10: Largest four occupational groups for engineering science graduates entering employment, 2002/03-2010/11. 


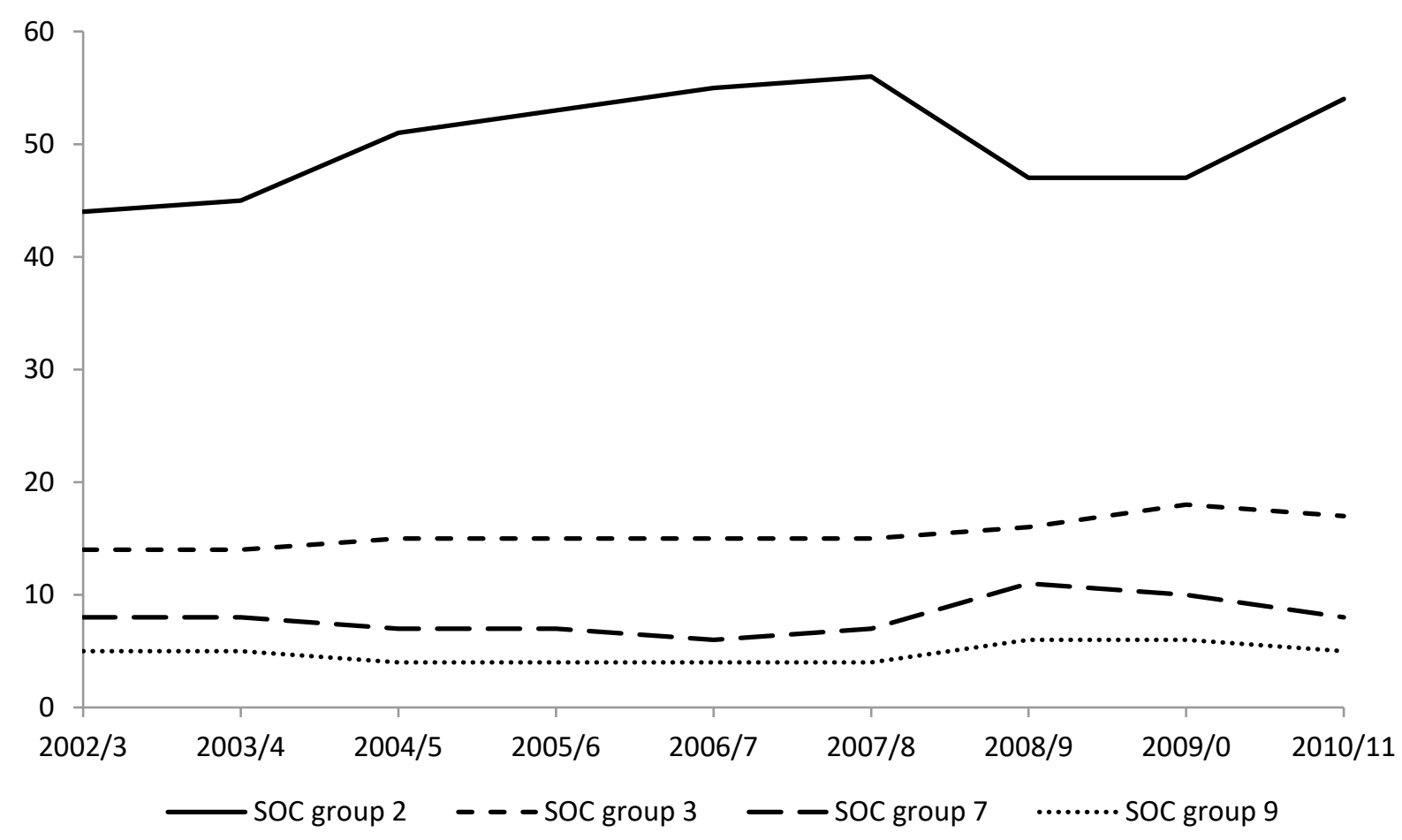

\section{Occupational destinations of STEM graduates: a snapshot from 2010/11}

The analysis of the occupational destination data for STEM graduates has shown that these have been relatively stable over the nine year period examined, particular in relation to SOC 2 and 3 jobs. In this section we look at the data for key subject areas in more detail. As there has been little change over the period studied, and due to considerations of space, we summarise the data for $2010 / 11$ only. In addition to presenting the data for the five main STEM subject areas, we also include the largest recruiting individual STEM subjects (Tables 2 and 3 ). Only occupations that attract over $5 \%$ of graduates are included in the findings.

It is worth remembering that entry to high-level graduate employment will differ according to subject discipline and occupational area. So, for example, it is much more likely that a graduate in medicine will enter an SOC 2 occupation six months after graduation than a biology graduate who might have to work in a SOC group 3 job beforehand. We are also not able to make any judgement about whether students who are less academically able or less financially secure are more likely to enter the workforce directly after graduation rather than undertake further study. Because of this it is important to be cautious in interpretations of what is the most 'desirable' destination after graduation. For some graduates, gaining employment in an SOC 3 occupation might be a perfectly appropriate outcome from their degree studies despite this perhaps being of 'lower status' than a SOC 1 or 2 level job.

What the data do enable us do, however, is to draw comparisons between similar subject areas. In the two tables that follow, comparisons are first made between occupational destinations for the biological and physical sciences (and selected main subjects). Table 3 presents the same data for the mathematical, computing and engineering sciences (and 
selected main subjects). For comparison we include occupational destination data for social studies and for historical and philosophical studies in both tables.

Biological science graduates (including those who studied sports science and psychology) were less likely to secure SOC 2 occupations than those from the other main STEM subject groups. Although the proportion entering SOC 2 jobs was, at 17\%, slightly higher for biology, this was still substantially lower than that for the other pure sciences. In chemistry, for example, over one-third of graduates secured SOC 2 jobs, even though similar proportions of graduates from both subjects entered full-time employment upon graduation (for example, in 2010/1 35\% of chemistry graduates and 31\% of biology graduates entered employment within six months of graduating). In comparison to chemists and physicists, those biologists who enter employment are also more likely to hold lower status or nongraduate posts; $39 \%$ of employed biology graduates held jobs in SOC 6-9 occupation categories six months after graduation, compared with $22 \%$ of chemistry graduates and only $14 \%$ of those with physics degrees.

Compared to graduates who studied non-STEM subjects such as social studies or historical studies, graduates from most STEM disciplines are more likely to secure employment in SOC 2 occupations. The exceptions here are graduates from the biological sciences of whom around $13 \%$ enter SOC 2 jobs, compared with $20 \%$ of social studies graduates. The relatively poor employment outcomes for biological science graduates do not only apply to 'lower status' courses such as sports science; both biology and psychology graduates also fare less well in the early graduate labour market both in comparison to other STEM graduates and compared to those from many non STEM subject areas as well. 
Table 2: Largest occupational destinations for graduates from biological and physical sciences and main subject areas, 2010/11

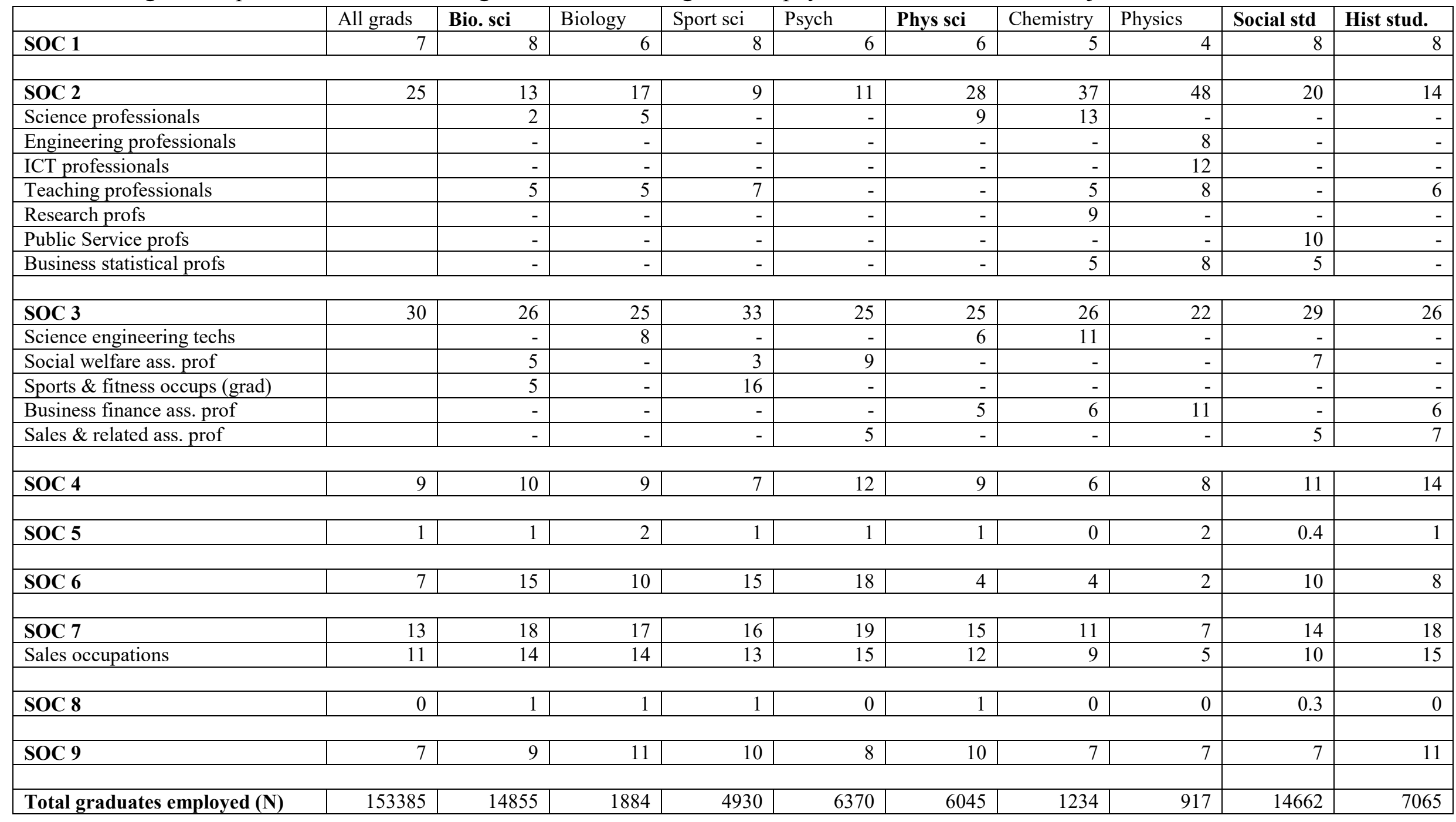


The destination data for physical science graduates appears to be more positive than that for graduates from the biological sciences, although there are notable differences within this subject group. As discussed above, despite being more likely to study extended length firstdegree programmes, around one-third of chemistry and physics graduates remain in full-time education after graduation (about half of whom study for higher research degrees). These are further examples of the differences within and between STEM subject groups. However, even when considering the most successful STEM subjects and subject groups, the labour market advantages are relatively small. The vast majority of graduates from every subject and subject group do not go into high status, highly skilled or graduate-level jobs within six months of graduating.

Turning to Table 3, we can see that the early occupational destinations for graduates from the mathematical and engineering sciences compare favourably with both the graduate population as a whole and many other STEM subject areas. The early employment trajectories for computer science graduates show two different patterns: one that shows a route into higher status SOC 2 jobs and a second that sees relatively large proportions of graduates taking non-graduate jobs. For example, over half of computer scientists go into full-time employment after graduation, a figure that is similar to that for the engineering sciences (Table 1). Among those who enter employment $47 \%$ of computer science graduates go into SOC 2 occupations with the majority working as ICT professionals. Only 7\% of computer science graduates find work in associate and technical positions in the IT industry. On the other hand, around $13 \%$ of computer science graduates entered SOC 7 occupations, a figure that is similar to the biological sciences and some non-STEM groups. Indeed the second largest occupational group for computer science graduates, after ICT professionals, was in elementary sales occupations in which $10 \%$ found work. The extent to which these polarised routes for computer scientists reflects the types of institutions in which they have studied is will be explored in further analyses and be the subject of a different paper. 
Table 3: Largest occupational destinations for graduates from mathematical, computing and engineering sciences and main subject areas, 2010/11

\begin{tabular}{|c|c|c|c|c|c|c|c|c|c|}
\hline & All grads & Math. Sci & Comp. Sci & Eng Sci. & Civil Eng. & Elect Eng. & Mech. Eng. & Social Stud. & $\begin{array}{l}\text { Hist. } \\
\text { studies }\end{array}$ \\
\hline SOC 1 & 7 & 5 & 6 & 7 & 8 & 6 & 6 & 8 & 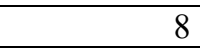 \\
\hline SOC 2 & 25 & 41 & 47 & 54 & 62 & 54 & 70 & 20 & 14 \\
\hline Engineering professionals & & - & - & 44 & 55 & 32 & 64 & - & - \\
\hline ICT professionals & & 7 & 41 & 5 & & 19 & - & - & - \\
\hline Public Service profs & & - & - & - & - & - & - & 10 & - \\
\hline Business statistical profs & & 24 & - & - & - & - & - & 5 & - \\
\hline SOC 3 & 30 & 26 & 19 & 18 & 11 & 18 & 10 & 29 & 26 \\
\hline ICT service delivery occs & & - & 7 & - & - & - & - & - & - \\
\hline Social welfare ass. prof & & - & - & - & - & - & - & 7 & - \\
\hline Business finance ass. prof & & 18 & - & - & - & - & - & - & 6 \\
\hline Sales \& related ass. prof & & - & - & - & - & - & - & 5 & 7 \\
\hline SOC 4 & 9 & 10 & 5 & 3 & 4 & 4 & 2 & 11 & 14 \\
\hline SOC 5 & 1 & 0 & 1 & 2 & 1 & 2 & 2 & 0.4 & 1 \\
\hline & & & & & & & & & \\
\hline SOC 6 & 7 & 3 & 1 & 1 & 1 & 1 & 1 & 10 & 8 \\
\hline SOC 7 & 13 & 9 & 13 & 8 & 8 & 9 & 5 & 14 & 18 \\
\hline Sales occupations & 11 & 7 & 10 & 7 & 7 & 7 & 4 & 10 & 15 \\
\hline SOC 8 & 0 & 0 & 1 & 1 & 1 & 1 & 1 & 0.3 & 0 \\
\hline SOC 9 & 7 & 5 & 4 & 5 & 5 & 6 & 4 & 7 & 11 \\
\hline Total graduates in employed (N) & 153385 & 2620 & 5462 & 7570 & 1385 & 1335 & 1692 & 14662 & 7065 \\
\hline
\end{tabular}




\section{Discussion}

There is no widely agreed definition of what constitutes a skills shortage. According to some commentators a shortage exists if the number of scientists and engineers, for example, is less than the number dictated by some social criterion or hypothetical demand. However, this perspective is largely based upon a value judgment about what contribution science and technology ought to make to society (Veneri 1999). Labour market economists offer a quite different definition of shortage conditions but one that is arguably more useful for the empirical study of supply and demand in the STEM sector:

Shortages occur in a market economy when the demand for workers for a particular occupation is greater than the supply of workers who are qualified, available and willing to do that job. (Veneri 1999:15)

So if a shortage does exist, economists would generally expect to see low unemployment, high wages, and a large number of unfilled posts, as employers compete to attract workers with scarce, yet desirable, skills. The findings presented in this paper suggest that, on the basis of the evidence available to us in this study, there is little evidence to support a shortage in the availability of STEM graduates from a number of disciplines.

One of the most interesting findings of this research is the relative stability of graduate destinations for students with degrees in all subjects. This is the case despite significant changes in higher education policy - such as the introduction of and subsequent increase in tuition fees - and major changes to the economic context in which graduates find themselves looking for work. While there is evidence of relatively small changes that could be attributed to the recession, the long term patterns in employment, unemployment and further study appear to be remarkably resilient. There is, however, some evidence of deskilling among those graduates who find non-graduate positions, with administrative roles being replaced by work in the customer service and personal service industries.

While levels of unemployment for recent graduates have remained reasonably stable over the past twenty years, they are among the highest, at around 10\%, for graduates from computer science and engineering degrees - two of the main subject areas in which shortages have been claimed. Additionally, around $20 \%$ of computer science graduates who do enter the workforce do so into low-skilled 'routine' occupations. The figure for engineering graduates is slightly lower, at $18 \%$, but the combined rates of unemployed and underemployed graduates does not seem congruent with a sector that is struggling to recruit graduates.

In addition to the relatively high proportions of computing and engineering graduates who are unemployed or employed in routine occupations after graduation, there is also a significant proportion that enter professional (but not technical) graduate-level work. So, as noted above, it seems that there are two routes for computer scientists and engineers following graduation: one that leads to highly skilled professional level work for a minority and another that leads to routine employment or unemployment. 
The first destinations of graduates from the physical, mathematical and biological sciences differ from those of the engineers and computer scientists in one key way - more of the former groups are likely to remain in education and undertake additional training prior to entering the workforce. A possible explanation for this is that their undergraduate degrees do not provide them with the necessary skills to enter the highly skilled STEM occupations they are aiming for and that additional study is required to make them desirable to employers. It should be remembered, however, that many of these students will have - like those in the engineering sciences - already studied for four years as undergraduates. Often this financial and personal commitment to additional study is taken with little guarantee of future stable and secure employment.

The biological sciences stand out as relatively weak in terms of employment outcomes. Like the physical sciences, they have lower than average rates of employment and also one of the lowest rates of employment in graduate-level jobs. It is also the case that those biological science graduates that found employment in non-graduate jobs were more likely to end up in lower-status and lower-skilled positions than their peers with degrees in other subjects. What is particularly surprising, however, is the extent to which this subject group supplies the highly skilled STEM workforce. Biological science graduates employed six months after graduation were three times less likely to be in highly skilled STEM jobs than engineering graduates and only half as likely as STEM graduates as a whole. In fact, social studies graduates had a similar level of employment in highly skilled STEM positions as those from the biological sciences. The variation between STEM subjects is in some respects much greater than the variation between STEM and non-STEM subjects. In terms of employment outcomes it is not very useful to group subjects in this way, as it can mask very important differences between subject groups and individual subjects.

The findings presented in this paper raise questions about the wider purpose of undergraduate STEM degrees and about the role of undergraduate study more widely. Given that students now pay substantial sums towards their tuition, to what extent is it acceptable for employers to expect that students graduate with a specific range of skills suited to a particular occupation? Undergraduate degrees aim to equip graduates with a wide and general understanding of a particular subject (albeit with some scope for specialisation), and considering the wide variety of STEM jobs, is this a realistic expectation for any curriculum? And to what extent do shortage narratives reflect unrealistic expectations of employers who are unwilling or unprepared to provide training and professional development to newly employed graduates? Surely, if a true shortage existed, there would be very few underemployed or unemployed graduates in these areas and employers would be prepared to offer suitable training for those who did not already have the required levels of skills and expertise? Could it be the case that it is in the interest of employers to be able to select employees from a labour market in which there is a surplus of suitable candidates?

Unrealistic expectations of employers are one possible explanation for the concerns they express about a 'shortage' of suitably qualified graduates. An alternative explanation could 
be that STEM graduates find STEM careers unattractive and the sector does not offer sufficient money or attractive opportunities to entice bright students away from employers outside the sector. Another reason may be that STEM employers themselves are poor recruiters. Some evidence for this is offered in the recent Review of Engineering Skills undertaken by Professor John Perkins (BIS 2013). In his view

...part of the problem is that STEM employers "aren't being as cunning as they might be" at attracting graduates. At careers fairs, he says, students say that representatives of banks and accounting firms are "all over you like a rash, trying to convince you to come into their world" whereas more traditional STEM employers are "shy and retiring and not as effective at persuading you that life could be exciting with them, too" (cited by Harris 2014)

Graduates from some non-STEM subjects also fare relatively poorly in the early graduate labour market but it is important to remember these are not subjects that we are repeatedly told are in crisis and neither are they subjects that attract considerable taxpayer support to assist with recruitment and delivery. Students studying the biological sciences, for example, pay the same fees as social studies students - despite the higher level of resources required for science degrees. As has been demonstrated in this paper, the extra government investment needed to run STEM degrees is not always repaid in terms of superior graduate outcomes, even in terms of supplying highly skilled STEM workers. An economic rationale for subsidising STEM education simply cannot be sustained for all subjects and subject groups. While there are plenty of other reasons why STEM education should be given a special status - such as the wider benefits of a scientifically literate population - these are not the grounds upon which currently policy making is justified. In the context of fees of $£ 9,000$ per year for many students, and amidst rumours of future fee rises, this is an issue that should be of concern to universities, students themselves and the taxpayer.

Perhaps the most important finding from this research is the small proportion of STEM graduates who find highly skilled STEM occupations within six months of graduating. Even in subjects such as engineering and computer science, where the shouts of 'shortage' and 'crisis' have been loudest and most sustained, only just over one-third of graduates are employed in these roles six months after graduating. In this context, how ethical is it to encourage young people to embark on STEM degrees on the promise of gaining prestigious employment in 'shortage' areas? To what extent can the continued subsidisation of STEM education be justified on economic terms? And given the increasing cost of a university education and the graduate destinations shown in this paper, is participation in higher education such a 'great way to get on' after all?

Acknowledgement: The research undertaken in this paper was funded by a grant from the Nuffield Foundation 


\section{Notes}

1. SIV subjects are designated by the Higher Education Funding Council for England (HEFCE) as Strategically Important and Vulnerable Subjects. Broadly, these are science, technology, engineering and maths, modern foreign languages and quantitative social science.

2. UCAS main subject group categories for STEM subjects:

- Medicine and Dentistry

- Subjects allied to Medicine: including Nursing and Pharmacy

- Biological Sciences: including Biology, Microbiology, Biochemistry Psychology, Sports Science

- Veterinary Sciences, Agriculture and related

- Physical Sciences: including chemistry, physics, physical geography and environmental and forensic science

- Mathematical and Computational Sciences

- Engineering and Technologies Sciences

- Architecture, Building and Planning

3. The relatively small proportion of students (around 8\%) who state that they are away 'travelling' or taking a gap year are included in a separate category by HESA; these data are not reported here.

4. Although at the time of writing data for the academic years beyond 2010/11 was available for analysis, HESA had changed the definitions of a number of key categories and therefore $2010 / 11$ is the last year for which comparable data that would enable us to track long terms trends is available.

5. In 2002 HESA moved from the SOC 1990 occupational classification to SOC2000 (ONS 2000). Data prior to 2002 is not comparable and so for occupational groups the analysis begins with graduates from the 2002/3 academic year.

6. SOC 2000 occupational classifications:

SOC Group 1 Managers and Senior Officials

SOC Group 2 Professional Occupations

SOC Group 3 Associate Professional and Technical Occupations

SOC Group 4 Administrative and Secretarial Occupations

SOC Group 5 Skilled Trades Occupations

SOC Group 6 Caring Personal Service Occupations

SOC Group 7 Sales and Customer Service Occupations

SOC Group 8 Process, Plant and Machine Operatives

SOC Group 9 Elementary Occupations 


\section{References}

BBC (2014) Skills shortages holding back the UK's economic recovery, BBC Online, accessed March 2015 from http://www.bbc.com/news/business-30224320

BIS (2009) The Demand for Science, Technology, Engineering and Mathematics (STEM) Skills. Available at: www.bis.gov.uk/assets/biscore/corporate/migratedd/publications/d/ demand_for_stem_kills.pdf(accessed March 2010).

BIS (2011), The returns to Higher Education Qualifications, Research report no. 45, London: Department for Business, Innovation and Skills

BIS (2013), Science and engineering teaching at English universities will receive a $£ 400$ million boost, Department for Business, Innovation and Skills press release $30^{\text {th }}$ September 2013, accessed from www.gov.uk/government/news/400-million-will-help-science-andengineering-students-get-ahead-in-the-global-race-and-encourage-more-women-to-studythese-subjects

Bush, V., (1945), Science the Endless Frontier, A Report to the President, Washington DC: US Government Printing Office.

CBI (2014), Gateway to growth: CBI/Pearson education and skills survey 2014, London: Pearson.

CBI (2014a), Engineering our future: Stepping up the urgency on STEM, London:

Confederation for British Industry

Chevalier, A., (2000), Graduate Over-Education in the UK, Centre for the Economics of Education Discussion Paper 7, London School of Economics.

Chevalier, A., Lindley, J., (2009), Overeducation and the skills of UK graduates, J. R. Statist. Soc. A 172, Part 2, pp. 307-337

Chowdry, H., Crawford, C., Dearden, L., Goodman, A. and Vignoles, A. (2010) Widening Participation in Higher Education: Analysis Using Linked Administrative Data. London: IFS/ESRC, accessed from: http://www.ifs.org.uk/wps/wp1004.pdf.

CIHE. (2009). The demand for STEM graduates and postgraduates, The Council for Industry and Higher Education STEM Policy Group, London: CIHE

Denham, J. (2008) 'Widening Participation', Speech to the Higher Education Funding Council Conference, 8 April, Warwick, UK, accessed from: www.dius.gov.uk/speeches/denham_HEFCE_080408.html 
DfES (2003) Widening Participation in Higher Education. London: Department for Education and Skills.

Department for Children, Schools and Families (2006) The Science, Technology, Engineering, and Mathematics Programme Report (London, DCSF). Available at: www.dcsf.gov.uk/hegateway/uploads/STEM\%20Programme\%20Report.pdf.

Dolton, P., Silles, M., (2003), The Determinants and Consequences of Graduate Overeducation, in Buchel, F., de Grip A., Mertens, A., (Ed.s), Over-education in Europe: Current Issues in Theory and Policy, Cheltenham: Edward Elgar.

Dolton, P., Vignoles, A., (2000), The incidence and effects of overeducation in the U.K. graduate labour market, Economics of Education Review 19 (2), pp179-198

Elias, P., Purcell, K., (2004), Researching Graduate Careers Seven Years On, SOC (HE): A classification of occupations for studying the graduate labour market, Research paper No. 6, Warwick Institute for Employment Research, accessed from www2.warwick.ac.uk/fac/soc/ier/research/completed/7yrs2/rp6.pdf

European Commission (2007), Science Education NOW: A renewed Pedagogy for the Future of Europe, The Rocard Report, Luxembourg: Office for Official Publications of the European Communities

Furlong, A., Cartmel, F. (2009) Higher Education and Social Justice. Buckingham: Open University Press.

Gago, J., Ziman, J., Caro, P., Constantinou, C, Davies, G., Parchmann, I., Rannikmae, $\quad$ M., Sjoberg, S. (2004). Increasing Human Resources for Science and Technology in Europe, Report of the High Level Group on Human Resources for Science and Technology in Europe, Luxembourg, European Communities.

Gannicott. K.G., Blaug, M., (1969), Manpower Forecasting since Robbins: A Science Lobby in Action, Higher Education Review, 2 (1): 56.

Gittoes, M., (2008), Graduates and their early careers, Bristol: Higher Education Funding Council for England, www.hefce.ac.uk/pubs/hefce/2008/08_39/08_39.pdf

Greenfield, S., Peters, J., Lane, N., Rees, T. and Samuels, G. (2002) A Report on Women in Science, Engineering, and Technology for the Secretary of State for Trade and Industry, accessed $\quad$ March 2010 from http://extra.shu.ac.uk/nrc/section_2/publications/reports/R1182_SET_Fair_Report.pdf.

Green, F., Zhu, Y., (2010), Overqualification, job dissatisfaction, and increasing dispersion in the returns to graduate education, Oxford Economic Papers 62, pp740-763 
Harris, M., (2014), The STEM shortage paradox, Physics World, October 2014, accessed March 2015 from http://live.iop-pp01.agh.sleek.net/2014/09/25/the-stem-shortage-paradox/

HEFCE (2008) Strategically Important and Vulnerable Subjects. Final report of the 2008 advisory group, accessed April 2010 from

www.stemnet.org.uk/db/_documents/strategic_subjects_final_report_08_20090323042053.p df

Higher Education Statistics Agency, (2015), Higher Education student enrolments and qualifications obtained at Higher Education providers in the United Kingdom 2013/14, Statistical First Release 210, Cheltenham: HESA

Higher Education Statistics Agency, (2013), Destinations of Leavers from Higher Education Institutions Longitudinal Survey 2008/09, Cheltenham: HESA

HM Treasury (2014), Our plan for growth: science and innovation, Presented to Parliament by the Minister of State for Universities, Science and Cities by Command of Her Majesty, Cm 8980, London: HM Treasury/Department for Business Innovation and Skills

IET (2013), Engineering and Technology: Skills and Demand in Industry, Annual Survey 2013, London: Institute of Engineering and Technology.

Krugman, P., (2014), Jobs and Skills and Zombies, New York Times, March 31, 2014, accessed March 2015 from http:/www.nytimes.com/2014/03/31/opinion/krugman-jobs-andskills-and-zombies.html?_r=1

Leitch Review of Skills (2006) Prosperity for All in the Global Economy - World Class Skills: Final Report (London, HMSO).

Marmot Review (2010) Fair Society, Healthy Lives: The Marmot Review Executive Summary, accessed from: http://www.ucl.ac.uk/marmotreview

Mellors-Bourne, R., Connor, H., Jackson, C., (2011), STEM Graduates in Non STEM Jobs, BIS Research Paper number 30, Cambridge: Careers Research \& Advisory Centre

Mosca, I., Wright, R.E., (2011), Is Graduate Under-employment Persistent? Evidence from the United Kingdom, Discussion Paper No. 6177, Bonn: Institute for the Study of Labour (IZA).

National Academy of Sciences (2010), Rising Above the Gathering Storm, Revisited: Rapidly Approaching Category 5, Washington DC: The National Academies Press 
ONS (2000), Standard Occupational Classification 2000 Volume 1, Newport: Office for National Statistics.

Select Committee on Science and Technology (2012), Higher Education in Science, Technology, Engineering and Mathematics (STEM) subjects Report, House of Lords Select Committee on Science and Technology, London: The Stationery Office Limited.

Smith, E. (2010) Do we need more scientists? A long term view of patterns of participation in UK Undergraduate Science Programmes, Cambridge Journal of Education, 40 (3), 281-298.

Teitelbaum, M.S. (2014), Falling Behind? Boom, bust and the global race for scientific talent, Princeton: Princeton University Press.

The Telegraph (2013), Shortage of engineers is hurting Britain, says James Dyson, $5^{\text {th }}$ September 2013, accessed from http:/www.telegraph.co.uk/finance/newsbysector/industry/engineering/10287555/Shortageof-engineers-is-hurting-Britain-says-James-Dyson.html

UCAS (2015), Applicants and acceptances by groups of applicants, UCAS Statistics on line, accessed from www.ucas.ac.uk

UKCES (2011), The supply of and demand for high- level STEM skills, UK Commission for Employment and Skills: Briefing paper, December 2011, accessed from www.ukces.org.uk/assets/ukces/docs/publications/briefing-paper-the-supply-of-and-demandfor-high-level-stem-skills.pdf

UKCES (2013), The supply and demand for high-level STEM skills, Evidence Report 77, London: UK Commission for Employment and Skills

Veneri, C.M., (1999), Can occupational labor shortages be identified using available data? Monthly Labor Review, Bureau of Labor Statistics, March 1999, pp15-21.

Wilkinson, G.C.G., Mace. J.D., (1973), Shortage or surplus of engineers: A review of recent UK evidence, British Journal of Industrial Relations, 11(1), pp105-123.

Wolf, A. (2000) Does Education Matter? Myths About Education and Economic Growth, London: Penguin.

Wright, J., Sissons, P., (2012), The Skills Dilemma Skills Under-Utilisation and Low-Wage Work, A Bottom Ten Million Research Paper, The Work Foundation. 